\title{
THE SASOL/ENGEN (UHAMBO) MERGER-FORECLOSURE AND WHITE FUEL DEMAND GROWTH RATES
}

\author{
Nicola Theron \\ Department of Economics, Stellenbosch University and Econex, Cape Town
}

\begin{abstract}
During October 2005, the Competition Tribunal heard evidence on the proposed merger between two large oil companies, Sasol Oil (Pty) Ltd and Engen Ltd. During the hearing it emerged that major aspects that would determine the outcome of the matter were:

- Potential foreclosure;

- Demand growth rates of white fuel; and

- Logistics.

The aim of this paper is to examine how the Tribunal dealt with the issue of potential foreclosure, by examining the expected growth rates of white fuels. The Tribunal had to consider the extent to which foreclosure in the oil industry would be profitable. This depended partly on expected growth rates in the demand for petrol and diesel. It will be argued that although there was conflicting evidence on this point, a proper analysis of economic variables such as expected economic growth rates, petrol demand elasticities and income elasticities, provided sound reasons for the Tribunal to prohibit the merger.
\end{abstract}

JEL G34, L41

\section{1 \\ Introduction}

During the latter half of 2005, the SA Tribunal considered the proposed merger in the oil industry between Sasol and Engen (the "Uhambo merger"). The merger hearing lasted several weeks, as there were several interveners (mostly the other major oil companies) who asked the Tribunal to prohibit the proposed merger. The final decision of the Tribunal, prohibiting the merger was released on the 23rd of February 2006. During the hearing it emerged that the outcome of this case would depend primarily on three issues:

- Foreclosure;

- Demand growth rates of white fuel; and

- Logistics.

During the merger hearing, the Tribunal heard from seventeen witnesses, of whom six were economists or economic experts (including the economist of the Competition Commission). Furthermore, the Tribunal considered a total of fourteen witness statements, of which three were written by economic experts.

The role of economists in these proceedings is not always well understood and is often criticised. Economists' contribution may be in the form of very complicated econometric models which then becomes a point of contention as it is true that any economic model is only as good as its assumptions. The Uhambo case has been no different and the divergence of economic models and econometric evidence caused the Tribunal (2006: 237) to remark in their final decision that: "'Garbage in; garbage out' is the caution customarily urged upon those who rely on econometric and other statistical techniques and while not all of the data used in the parties' model is to be so characterised, some of it does appear sufficiently contrived to warrant that description". 
It became clear during the hearing that the outcome of the case depended on the profitability of foreclosure. There was some consensus on the basics of the oil industry structure and market definition. The Tribunal took the view that since their analysis showed that the merger will lead to a substantial lessening of competition in the markets for petrol and diesel, it was not necessary to further examine all the other petroleum product markets (e.g. bitumen, heavy fuel oils, LPG, jet fuel, etc.). There was therefore not the usual dispute about the relevant product market that often emphasises the role of the economist in demarcating the relevant market for competition purposes.

Similarly, the definition of the relevant geographic markets was relatively straightforward. The history of the Main Supply Agreement (MSA) implied a separate geographic market known as the "inland market for refined fuels". The Tribunal found that the geographic upstream market was inland (the so-called market for "bulk supply"), and that the geographic downstream (retail) market was national.

Given the fact that there was no real dispute on market definition, it was common cause that Uhambo would have controlled more than 80 per cent of the output of refined fuel products in the inland geographical market and that its retail network would have accounted for approximately 40 per cent of inland fuel sales.

The aim of this paper is to show that on a very basic (and crucial) point of the Uhambo analysis, namely the demand growth rates of white fuels, economic analysis could have provided very clear answers. In what follows, the evidence put forward by the economists for both the merging parties and the interveners will be examined to see which followed established economic principles and theory.

\section{2}

\section{Foreclosure and the relevance of white fuels demand growth rates}

The Uhambo merger presented horizontal as well as vertical concerns. Given the high market shares in both the upstream and downstream markets that Uhambo would have obtained, the impact on both the upstream and downstream markets would ordinarily have to be examined. However, given the Tribunal's definition of the relevant upstream market as the inland market, there was no horizontal overlap between the Sasol and Engen refineries (Engen owns the Enref refinery which is situated at the coast). At the retail level, the horizontal effect would have been a total national market share of 34 per cent of petrol sales and 36 per cent of diesel sales, for Uhambo. Although this was considered to be an important issue, the focus throughout the hearing was on the vertical issues raised by the proposed merger.

The primary economic concern with vertical mergers is the ability of the merged firm to "foreclose" its rivals and to "raise rivals' costs". In the case of Uhambo, the majority of the economists focused on the issue of potential foreclosure. The vertical issue was clear - the merger would combine the substantial upstream refining capacity of Sasol with the significant wholesale and retail capacity of Engen. This immediately raised the prospect of input foreclosure, and the Tribunal also chose this as their main focus.

However, in order to prove that foreclosure would be profitable, the economists built some sophisticated models to present various foreclosure scenarios. The economist for the merging parties demonstrated in his model that foreclosure would not be profitable. This was disputed by the economists for the other oil companies who presented models that showed that foreclosure would be profitable.

This highlights the usual debate around economic analysis; there will always be economic experts who will argue for and against certain mergers or prohibited practices. But the outcome of the models depends on the assumptions. The foreclosure models all had to make certain assumptions regarding the aspects of demand growth for retail petrol and diesel and the current state of the logistics infrastructure.

When analysing potential foreclosure as a result of a vertical merger, economists have to consider the ability of the merged entity to foreclose, the costs of doing so and the factors that will affect the returns of such a strategy. The 
foreclosure analysis in the Uhambo case was specifically sensitive to different demand growth scenarios. It is shown in Figure 1 on page 269 that in 2003 there was already a shortfall in the inland market between demand and supply of petrol, diesel and jetfuel. Given the logistics constraints in terms of pipeline capacity in transporting fuel from the coast to the inland area, the other oil companies would have remained dependent on Uhambo for sufficient supplies to service their retail networks in the inland area (up to at least 2010 which was the expected completion date of a new pipeline). This would have given Uhambo the ability to foreclose. Uhambo would also have had an incentive to foreclose as it would have been more profitable to supply its own retail network, in the face of high demand growth for inland fuel. With low white fuels demand growth rates (such as those estimated by the parties to the merger), the possibility of foreclosure would seem rather remote. Conversely, high demand growth rates especially in the inland market would permit Uhambo to rapidly gain market share and thus significantly strengthen the ability of Uhambo to self-deal and to foreclose its rivals to its upstream production. High demand growth for white fuels would therefore increase the returns from a foreclosure strategy and would make such a strategy more feasible.

The logistics constraints faced by the other oil companies (the pipeline constraints as well as road and rail constraints), also contributed to the likelihood of foreclosure. The Tribunal noted that whereas under the previous Main Supply Agreement (MSA), the oil companies had to purchase all their inland requirements from Sasol, the fact that they were free to ship product from the coast post-MSA did not mean that it was truly a national market. "However what was previously constrained by agreement, is now constrained by logistical capacity - the inland marketers may import product from the coast, but because of inadequate logistical capacity they are only able to supply a portion of their needs (2006: 66)." Although logistic capacity was the other vital leg of the foreclosure models, ultimately the state of logistics were to be determined from the evidence of the factual witnesses of the various oil companies. Economists could not testify as to the true state of the logistics capacity and had to accept the evidence provided to them by the oil companies.

This paper will focus therefore on the issue of petrol and diesel demand growth and the way it was dealt with in the Uhambo merger, which finally determined the outcome of the foreclosure analysis. Foreclosure, although ultimately the decisive factor in the Uhambo decision, will not be further dealt with here. It should be briefly stated though, that the Tribunal finally decided that the "credible threat" of foreclosure was enough to prohibit the merger. In their own words: "Neither the Tribunal, nor the Commission, nor the merging parties, nor the intervenors, can decide with absolute certainty - beyond all reasonable doubt - whether or not foreclosure will be profitable. We can however say with confidence that it is a credible threat (2006: 87)." This finding of a credible threat of foreclosure ultimately caused the Tribunal to prohibit the proposed merger.

3

\section{Demand growth rates for petrol and diesel- economic theory}

The demand growth for petroleum products is the focus of the current paper. There were widely divergent views on the demand growth rates forecasted for petrol and diesel. Yet, the forecasting of demand growth rates is not a Herculean task for economists who should consider this as part of their basic toolkit. Economists know that the demand for any retail product is generally a function of the price of the product, income of consumers, the size of the population and the price of substitutes or complementary products. In some instances, product specific factors and consumer tastes are also included in the demand function, but researchers often find it difficult to incorporate qualitative variables (e.g. tastes) into demand equations. When specifying demand equations, such as those for petrol and diesel demand, various macroeconomic variables can be considered and tested for significance with the dependent variable (demand). The important point to make is that the choice of variables does not depend primarily on the "goodness of fit" 
or the correlation values, but has to be based on economic theory.

As the demand growth rates for petrol and diesel were one of the main issues considered by the Competition Tribunal, it is important to ask what value can be added by economists forecasting such growth rates. Before considering the variety of growth rates that were presented to the Tribunal by the various parties, it is important to say one or two things about the estimation of petrol and diesel demand.

The economist who has to estimate such growth rates will as a first step, based on economic theory, ask what might determine the demand for a specific product. This question must be answered with reference to the general determinants of demand, as set out above. The next step would be to look at the literature to ascertain what other researchers have found to be relevant determinants.

The demand for petrol is a well-researched topic in economic theory. The literature shows that both price and income have an effect on the amount of petrol purchased by consumers. But the consensus in the literature is that the income elasticity is generally higher than the price elasticity. In other words, petrol and diesel sales (in volume terms) are more sensitive to changes in consumer income (or GDP) than to changes in the real price of petrol or diesel.

Drollas (1984) did one of the early reviews of price and income elasticity in 1984 . He surveyed mostly US studies and found that the consensus view was that the long run price elasticity of demand was around -0.8 while the long run income elasticity was slightly below unity. Some studies (Blum et al., 1988) found larger ranges for some European countries, with an income elasticity varying between 0.86 and 1.90. Sterner (1990) used pooled data for OECD countries and found long run income elasticities of between 0.6 and 1.6. With another technique (time series data), he found the income elasticity to vary between 1.1 and 1.3.
Later work by Goodwin (1992) generally found that elasticity estimates had to be revised upwards from estimates calculated between the 1980s and 1990s. The extent to which strong economic performance will affect fuel demand is quantified by the income elasticity of the demand for fuel. More simply, the income elasticity measures the response of motorists to an increase in income. This is assumed to be a positive relationship. Graham and Glaister (2002: 1) in a comprehensive survey found that the long-run income elasticity of fuel demand falls in the range of 1.1 to 1.3 , and between 0.35 and 0.55 in the short-run.

Later work by Dahl and Roman (2004) looked at a total of 190 new studies since 1991 that dealt with energy demand. Their results generally correspond with the earlier findings of Graham and Glaister (2002), who found that the short run price elasticity of the demand for petrol typically falls between -0.2 and -0.3 , and the long run price elasticity between -0.6 and -0.8 . Dahl and Roman found that the mean value of the long run income elasticity for diesel was above 1 (1.13), and for petrol, the value was 0.69 . These values are once again in line with the earlier research summarised above.

Data on comparable middle-income countries are not as widely available as data for industrialised countries. Ramanathan examined fuel demand for India in 1999. The author found a short run income elasticity of 1.18 and a long run income elasticity of 2.68. These estimates are very high, compared to the international benchmarks from industrialised countries. Ramanathan believes that the low level of fuel consumption in India and the gradual increase in economic growth can explain the differences between his results and those obtained elsewhere (Graham \& Glaister, 2002: 17).

The following table summarises the results of similar studies done for the South African economy. 
Table 1

Data on South African white fuels price elasticities

\begin{tabular}{|l|l|c|c|}
\hline Source & Country & $\begin{array}{l}\text { Short-term price } \\
\text { elasticity }\end{array}$ & $\begin{array}{l}\text { Long-term price } \\
\text { elasticity }\end{array}$ \\
\hline S.A. Cloete \& vd M. Smit (1988) & South Africa & -0.25 & -0.37 \\
\hline S.D. Ngumedi (1994) & South Africa & \multicolumn{2}{|c|}{-0.1 to -0.2} \\
\hline $\begin{array}{l}\text { Bureau for Economic Policy } \\
\text { Analysis (1989) }\end{array}$ & South Africa & & -0.31 \\
\hline $\begin{array}{l}\text { Bureau for Economic Research } \\
\text { (BER) (2003) }\end{array}$ & South Africa & $\begin{array}{c}\text { Petrol }-0.21 \\
\text { Diesel }-0.18\end{array}$ \\
\hline
\end{tabular}

Source: BER, 2003

It follows from the above that based on economic theory and international models used to estimate petrol demand, the two variables that have to be included in any petrol or diesel demand function are the income and price variables. Based on the difference between the long-run price and income elasticities, it is also clear that the income variable has a larger effect than the price variable. The income variable is therefore the most important explanatory variable in petrol and diesel demand functions. Before looking at the specific choice of variables, it is worth stating the economic assumptions very simply. If there is an increase in income, people earn more and they have more disposable income, which will increase their demand for petrol, as they buy more or bigger cars, or go on more holidays or generally use their cars more. The data on long-term income elasticity suggest that this is a positive relationship with values that vary quite widely. And, it is quite likely that the percentage increase in fuel demand will be higher than the percentage increase in income, especially for developing countries.

The relationship between the price of petrol (or diesel) and the demand for petrol (or diesel) is a negative relationship (indicated by the minus sign on the price elasticities). The economic reason is simple: as the price of a product increases, the demand decreases.
Having found then, based on available economic literature that there are strong positive relationships between income and petrol demand and income and diesel demand, and a smaller negative relationship between the price and demand, the economist can use a time series for these independent variables to estimate the petrol or diesel demand growth rates. This is fairly straightforward, as long as good estimates of the forecasted variables can be obtained. The petrol and diesel prices are notoriously difficult to forecast, but there are estimates available. But given the strong correlation between income and the demand for petrol, good results could have been obtained by only using the correlation between income and petrol demand. In fact, this approach was used by the economists for Shell, as will be explained below.

\section{4}

\section{Demand growth rates - estimates of the economists}

\section{Petrol demand and supply balance}

The following graphs show the inland demand and supply situation for 2003 and 2010, as forecasted by BP (one of the interveners) at the time of the hearing. 


\section{Figure 1}

Inland demand and supply (2003 and 2010)
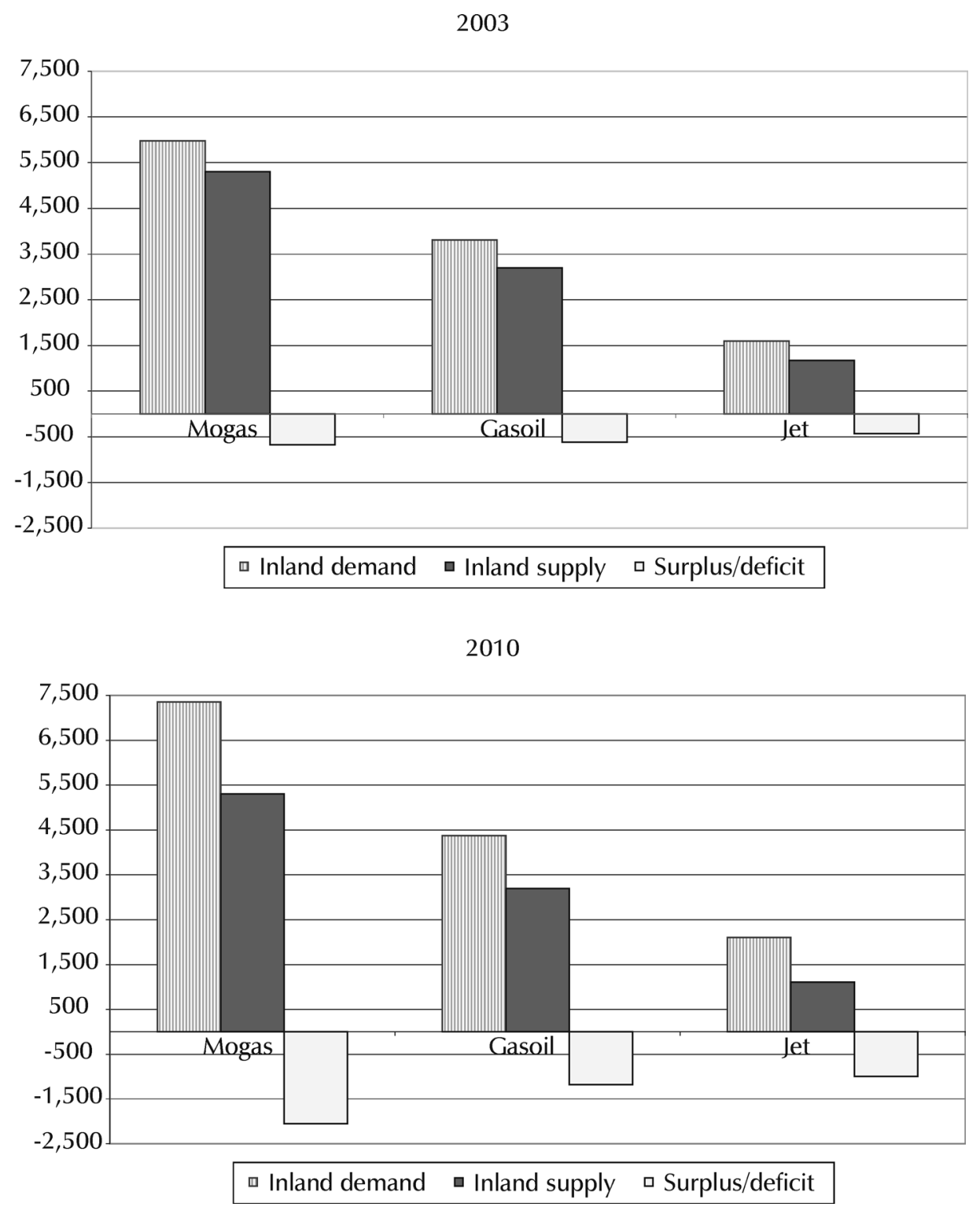

Source: BP, 2005

The important point to note is that in 2003 there was already a shortfall in inland supply for Mogas (petrol), Gasoil (diesel) and Jet (Jetfuel). In order to meet the inland demand, the balance was transported from the coastal areas by the oil companies, either via rail, road or pipeline. The second graph shows the dramatic increase in the deficit for all products in the face of rapid demand growth. Given infrastructure constraints and the time it would take to build a new pipeline from Durban to the inland area, the graphs illustrate that there would have been an incentive for the merging parties to foreclose on the other oil companies in the inland market. This is due to the increased profitability of a foreclosure strategy in the face of high demand growth and demand exceeding supply in the inland area. The merged entity would find it 
more profitable to supply its own downstream retail network due to the limited supply, and this would increase the costs of its rivals as it will have to import product at a higher cost from its own refineries at the coast.

Against this background, one can then consider the various estimates of demand growth presented by the merging parties as well as the interveners.

\section{Growth forecasts and their foundations}

Using a petrol and diesel demand model developed by the Bureau for Economic Research (BER) one of the interveners (Masana) presented the following petrol and diesel demand growth forecasts.

Table 2

Petrol and diesel growth rates for the national market and for the inland market

\begin{tabular}{|c|c|c|c|c|c|}
\hline \multicolumn{6}{|c|}{ PETROL NATIONAL MARKET } \\
\hline Year & Demand $^{1}$ & Growth (\%) & Capacity & Surplus & Surplus (\%) \\
\hline 2004 & 11918 & & 13202 & 1284 & $10.8 \%$ \\
\hline 2005 & 12550 & $5.3 \%$ & 13202 & 652 & $5.2 \%$ \\
\hline 2006 & 12964 & $3.3 \%$ & 13202 & 238 & $1.8 \%$ \\
\hline 2007 & 13340 & $2.9 \%$ & 13202 & -138 & $-1.0 \%$ \\
\hline 2008 & 13753 & $3.1 \%$ & 13202 & -551 & $-4.0 \%$ \\
\hline 2009 & 14276 & $3.8 \%$ & 13202 & -1074 & $-7.5 \%$ \\
\hline \multicolumn{6}{|c|}{ DIESEL NATIONAL MARKET } \\
\hline Year & Demand & Growth (\%) & Capacity & Surplus & Surplus (\%) \\
\hline 2004 & 8621 & & 10580 & 1959 & $22.7 \%$ \\
\hline 2005 & 9131 & $5.9 \%$ & 10580 & 1449 & $15.9 \%$ \\
\hline 2006 & 9467 & $3.7 \%$ & 10580 & 1113 & $11.8 \%$ \\
\hline 2007 & 9799 & $3.5 \%$ & 10580 & 781 & $8.0 \%$ \\
\hline 2008 & 10328 & $5.4 \%$ & 10580 & 252 & $2.4 \%$ \\
\hline 2009 & 10927 & $5.8 \%$ & 10580 & -347 & $-3.2 \%$ \\
\hline \multicolumn{6}{|c|}{ PETROL INLAND MARKET } \\
\hline Year & Demand & Growth (\%) & Capacity & Surplus & Surplus (\%) \\
\hline 2004 & 5779 & & 5769 & -10 & $-0.2 \%$ \\
\hline 2005 & 6085 & $5.3 \%$ & 5769 & -316 & $-5.2 \%$ \\
\hline 2006 & 6286 & $3.3 \%$ & 5769 & -517 & $-8.2 \%$ \\
\hline 2007 & 6468 & $2.9 \%$ & 5769 & -699 & $-10.8 \%$ \\
\hline 2008 & 6669 & $3.1 \%$ & 5769 & -900 & $-13.5 \%$ \\
\hline 2009 & 6922 & $3.8 \%$ & 5769 & -1153 & $-16.7 \%$ \\
\hline
\end{tabular}




\begin{tabular}{|c|r|r|r|r|c|}
\hline \multicolumn{7}{|c|}{ DIESEL INLAND MARKET } \\
\hline Year & Demand & Growth (\%) & Capacity & Surplus & Surplus (\%) \\
\hline 2004 & 3640 & & 3545 & -95 & $-2.6 \%$ \\
\hline 2005 & 3855 & $5.9 \%$ & 3545 & -310 & $-8.0 \%$ \\
\hline 2006 & 3997 & $3.7 \%$ & 3545 & -452 & $-11.3 \%$ \\
\hline 2007 & 4137 & $3.5 \%$ & 3545 & -592 & $-14.3 \%$ \\
\hline 2008 & 4361 & $5.4 \%$ & 3545 & -816 & $-18.7 \%$ \\
\hline 2009 & 4614 & $5.8 \%$ & 3545 & -1069 & $-23.2 \%$ \\
\hline
\end{tabular}

Source: BER/ Econex, 2005.

The table above shows how the demand (in millions of litre) would increase given an initial level of demand in both the national and inland markets. According to this forecast, the average growth rate for petrol over the five years would be 3.7 per cent and for diesel over the same period, 4.9 per cent.

These growth rates were significantly higher than those presented by the merging parties.
The following graph compares the shortfall of petrol in the inland market in 2009 based on four different scenarios. Scenario 1 is that of the BER as described above, scenario 2 is a "low" scenario of constant 2 per cent growth in petrol demand, scenario 3 assumes a constant growth rate of 4 per cent, and the last bar in the graph below is based on the forecast of the merging parties.

Figure 2

Petrol shortfall (2009): Inland market

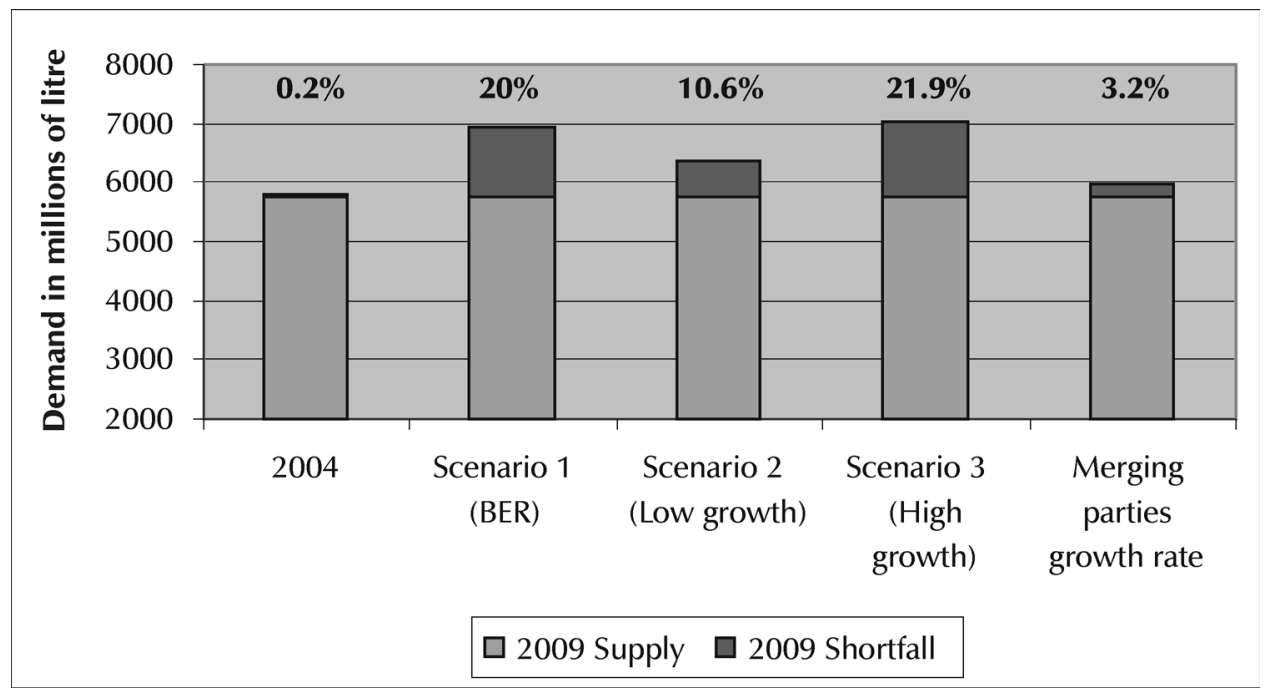

Source: Econex, 2005

Figure 2 illustrates again the sensitivity of the foreclosure scenario to the different forecasts of the growth in petrol demand. The merging parties argued that the shortfall will be minimal even up to 2009 and that any further shortfall will be overcome by the upgrading of the existing pipeline that runs from Durban to the inland area (the "DJP pipeline").

The Tribunal summarised the growth rate of petrol demand forecasts of the parties as follows: 
Table 3

Various estimates of petrol demand growth rates

\begin{tabular}{|l|c|}
\hline \multicolumn{1}{|c|}{ Source } & Petrol demand growth rate \\
\hline RBB (for BP) & $3 \%$ \\
\hline Econometrix & $2.2 \%$ \\
\hline Total (2005-2014) & $2.2 \%$ \\
\hline RBB (for Shell) & $2 \%$ \\
\hline ECONEX (for Masana) & $3.6 \%$ \\
\hline Sasol (2006 budget) & $1.4 \%$ \\
\hline Uhambo business plan & $1 \%$ \\
\hline
\end{tabular}

Source: Tribunal, 2006, p. 91

The Tribunal (2006: 92) noted in its decision regarding the growth estimates of the various economists that: "We have been presented by bald estimates by the participants in these hearings - many of whom appeared to rely on independent experts - but surprisingly few have attempted to explain the underlying basis for their estimates". This is a serious criticism against the economic evidence that was presented during the hearing. The Tribunal had to come to their own conclusions regarding the determinants of petrol demand (2006: 92): "In our view, common sense would suggest a high degree of correlation between income growth and rates of fuel consumption. It may also reasonably be hypothesised that changes in the distribution of income would correlate with shifts in demand for fuel products."

We have argued above, based on the economic evidence on the income elasticity and price elasticity of demand for petrol, that the positive income effect is more important than the negative price effect. The Tribunal also referred to the positive correlation between income and fuel demand. When developing a model to explain the demand for petrol, one has to choose the appropriate income variable. Although there is a positive correlation between the gross domestic product (GDP) and petrol demand, most studies on petrol demand find that real disposable income of households explains petrol demand better than GDP. This income variable makes sense intuitively, as petrol sales to households constitute a large proportion of total petrol sales. Real disposable income is the key driver of demand for most retail products, including petrol sales to households.

The evidence from the literature as well as the SA data is that the income variable is the most important determinant of fuel demand; the GDP growth rate in the case of diesel and real disposable income in the case of petrol. There is a negative relationship between the real prices and volumes sold, but this relationship is weaker than the income relationship.

In order to use this information to forecast growth rates for petrol and diesel, one needs to develop an econometric model that can incorporate these relationships. But before moving to an overview of the formal models presented to the Tribunal by the various parties, it is worth noting that at the time of the hearing, South Africa experienced the longest upswing in economic growth since 1970 . This would a priori lead one to assume that this increase in general economic activity would also have implied higher demand for fuel. At the time of the hearing, the GDP forecast of the National Treasury for growth was exceeding 4 per cent between 2005 and 2007. The Bureau for Economic Research at that stage had an average GDP growth forecast of 3.7 per cent between 2005 and 2009 .

\section{Economic models used}

The literature and SA data confirm the assumption of the Tribunal that there is a high correlation between income growth and growth in the demand for petrol. Given this high 
correlation, one can assume that much of the demand for petrol and diesel can be explained by using only an income variable.

\section{a) Shell}

This was the approach taken by one of the interveners, Shell. They used the following formulas to forecast the demand for petrol and diesel. Although both equations are affected by the fact that there is only one variable, and that GDP (rather than disposable income) was used in the case of petrol, Shell presented these as a general indication of what drives petrol and diesel demand.

- $\quad$ Demand for petrol $=($ GDP -1.5 per cent $)$

- $\quad$ Demand for diesel $=($ GDP +1.4 per cent $)$

Applying these formulas, the economists for Shell (RBB Economics) made the following forecasts for growth in petrol and diesel demand.

Table 4

Shell demand forecasts for the Uhambo hearing

\begin{tabular}{|l|c|c|c|c|c|c|}
\hline & $\mathbf{2 0 0 5}$ & $\mathbf{2 0 0 6}$ & $\mathbf{2 0 0 7}$ & $\mathbf{2 0 0 8}$ & $\mathbf{2 0 0 9}$ & $\mathbf{2 0 1 0}$ \\
\hline GDP growth & $3.5 \%$ & $3.7 \%$ & $4.4 \%$ & $3.3 \%$ & $2.9 \%$ & $3.0 \%$ \\
\hline Petrol demand growth & $2.0 \%$ & $2.2 \%$ & $2.9 \%$ & $1.8 \%$ & $1.4 \%$ & $1.5 \%$ \\
\hline Diesel demand growth & $4.9 \%$ & $5.1 \%$ & $5.8 \%$ & $4.7 \%$ & $4.3 \%$ & $4.4 \%$ \\
\hline
\end{tabular}

Source: Uhambo, economic report filed by RBB for Shell, 2005.

The question is whether such a 'rule of thumb' gives an adequate forecast of the real demand. The following two graphs show what happens if we use the formula of Shell and apply that to historic demand data for petrol and diesel.

Figure 3

Shell petrol demand growth forecasts vs real petrol demand growth.

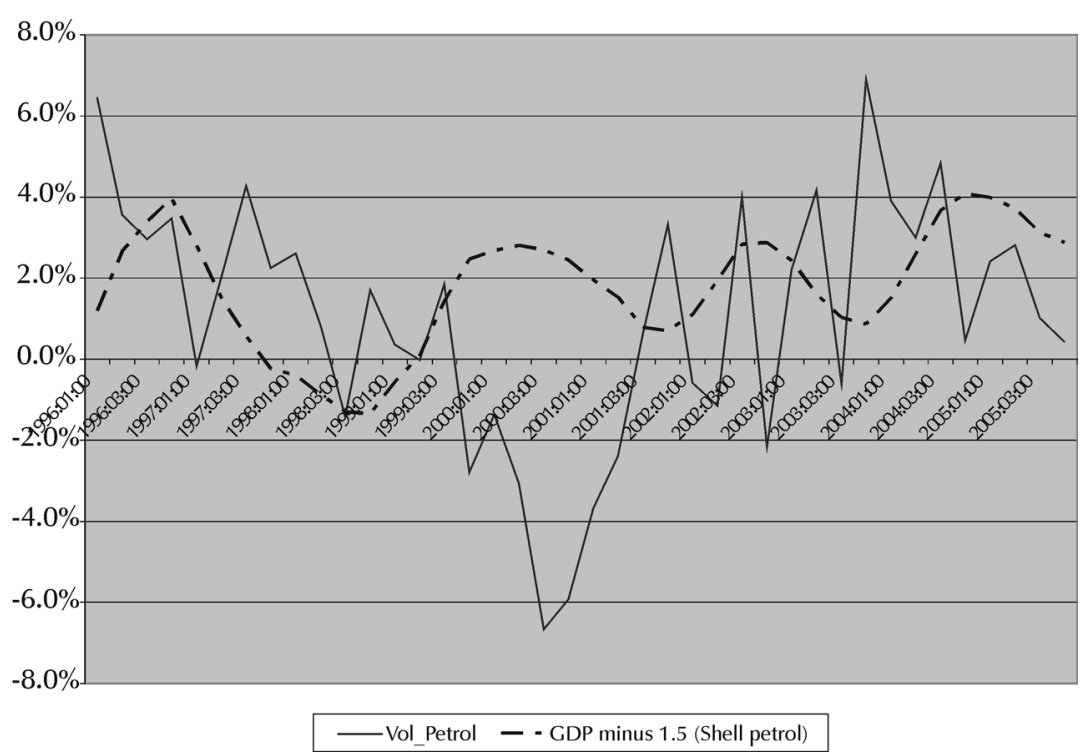




\section{Figure 4}

Shell diesel demand growth forecasts vs real diesel demand growth.

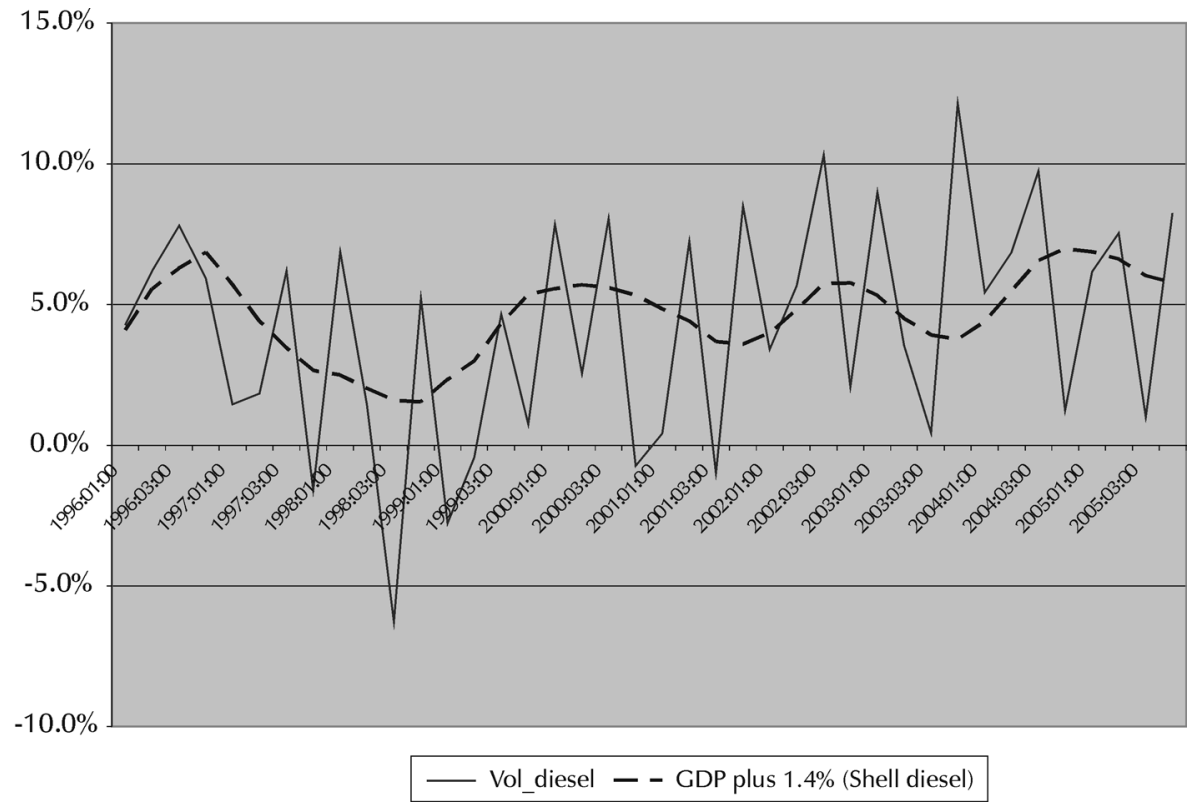

Source: own calculations

It is clear from the graphs above that the Shell formula does not capture all of the fluctuations in the volumes. A simple examination of the graphs shows that the diesel graph seems to have a better fit than the petrol graph. The next step would be to add more explanatory variables to increase the predictive power of the models.

\section{b) Masana (BER)}

Masana based their demand forecasts on a petrol demand model that was developed by the BER. The BER estimated the demand for petrol and diesel in 2005, based on quarterly data between 1984 and 2004. They used seasonally adjusted volume sales of petrol and diesel as dependent variables. A regression analysis yielded a model where the volume sales of petrol are explained by real disposable income of households and the real (inflation-adjusted) price of petrol. This model had an R-squared value of 0.71 . The results of this model suggest that the demand for petrol (volume sales) is relatively inelastic with regard to changes in the real retail price of petrol. The short-run price elasticity was -0.19 and the long-run elasticity -0.62 . The short-term income elasticity of petrol in SA was found to be around 0.10 , while the long-run income elasticity was around 1.0.
For diesel, the BER regression results showed that seasonally-adjusted volume sales of diesel are explained by the gross domestic product and the real (inflation-adjusted) price of diesel. However, the demand for diesel was found to be less sensitive to price changes than the demand for petrol. (This might explain why the Shell model yielded a better outcome for diesel demand than for petrol demand (where the price variable was omitted). The diesel demand model had an R-squared value of 0.63 . The long-run demand elasticity for diesel was found to be -0.1 . The long-run income elasticity was calculated as 1.36 (BER, 2005: 6).

While the BER found that South Africa's long-run income elasticity for both petrol and diesel seem to be in line with international research, it might be the case that income elasticities are higher in developing countries. There may be several explanations for this. As more people become economically active and the economy keeps growing, the number of cars purchased may increase and this will lead to an overall increase in the demand for petrol. Over time, the income elasticity may decrease as the country develops, while still remaining positive. 


\section{c) $B P$}

The other interveners also presented growth forecasts. BP based their forecasts on analysis by Econometrix. The report by Econometrix also found demand and income elasticities in the same range as that of the BER.

Table 5

Demand elasticities - 1999-2004

\begin{tabular}{|l|c|c|}
\hline & Price elasticity & Income elasticity \\
\hline Petrol & -0.238162 & 0.381192 \\
\hline Diesel & -0.138065 & 1.474488 \\
\hline
\end{tabular}

Source: Table 2.1 - Econometrix report, par. 2.2.2

Econometrix used real GDP as the income variable for both diesel and petrol. It was argued above that for petrol demand, real disposable income of households would be a better income variable. Based on this model, BP predicted a petrol demand growth rate of 3 per cent over the relevant period.

\section{d) Sasol and Engen}

The economists for the merging parties did not present a formal economic model to base their fuel demand growth forecasts on. They accepted the growth forecasts that came from the business plans of the merging parties, and therefore predicted that the current (at the time of the merger) best estimates was a petrol demand growth rate over the relevant period of 1.4 per cent, a diesel demand growth rate of 3.4 per cent and a kerosene demand growth rate of 2.9 per cent. In the original Uhambo business plan presented to the Competition Commission, the petrol demand was predicted to grow by only 1 per cent (see Table 5 above).

Especially in the case of petrol, such low demand growth rates would have minimised the threat of foreclosure. The higher diesel growth rate was assumed to be driven by factors such as the governments' taxi recapitalisation plan and consumers' increased preference for diesel vehicles.

The following petrol demand equation was presented by the merging parties (it appeared in the affidavit of Millard \& Kanfer (Business Enterprises at the University of Pretoria), p. 8).

$$
\begin{aligned}
\text { PETROSSA }= & \beta_{0}+\beta_{1} \text { CPI }_{-1}+\beta_{2} \text { REALPP }+\beta_{3} \mathrm{JAN}+\beta_{4} \text { FEB }+\beta_{5} \text { APRIL }+\beta_{6} \text { MAY } \\
& +\beta_{7} \text { DEC }+\mu
\end{aligned}
$$

In the equation above, the dependent variable is the nominal Rand value of petrol sales (PETROSSA). This is then specified as a function of the consumer price index (lagged), the real petrol price and various dummy variables to model the seasonal effects of petrol demand. There is no income variable.

This model clearly disregards the body of economic theory set out above as well as the evidence from the SA data described above. What the merging parties' model stated in essence is that there is a positive relationship between the demand for petrol and the CPI, and between the demand for petrol and the real price of petrol. Economic theory predicts that inflation (i.e. price increases) erodes the purchasing power of households, in other words, the higher inflation or prices become, the less consumers can afford in volume terms (i.e. with a given budget, they can afford to buy less petrol in volume terms). Increasing inflation will therefore reduce consumers' demand for petrol, i.e. if anything, there should be a strong negative relationship between inflation and petrol sales.

It is therefore impossible to find a positive relationship between CPI and real petrol sales. The equation above is flawed as the positive correlation was found between the nominal value of petrol sales and the level of the CPI. A positive correlation is meaningless as the correlation between most nominal variables in 
the economy would be positive, if inflation is not accounted for.

The correct way to deal with this issue would be to examine the relationship between the real petrol demand and the real petrol price (as was done in the model of the BER described above). The real petrol price was the second explanatory variable in the equation of the merging parties, and was also found to be positively correlated to the nominal petrol sales. However, when the year on year changes in the real values are used, one finds a negative relationship (with a correlation coefficient of -0.73 ), as illustrated below (Figure 5).

Figure 5

Negative relationship between petrol sales and real (CPI deflated) price of petrol

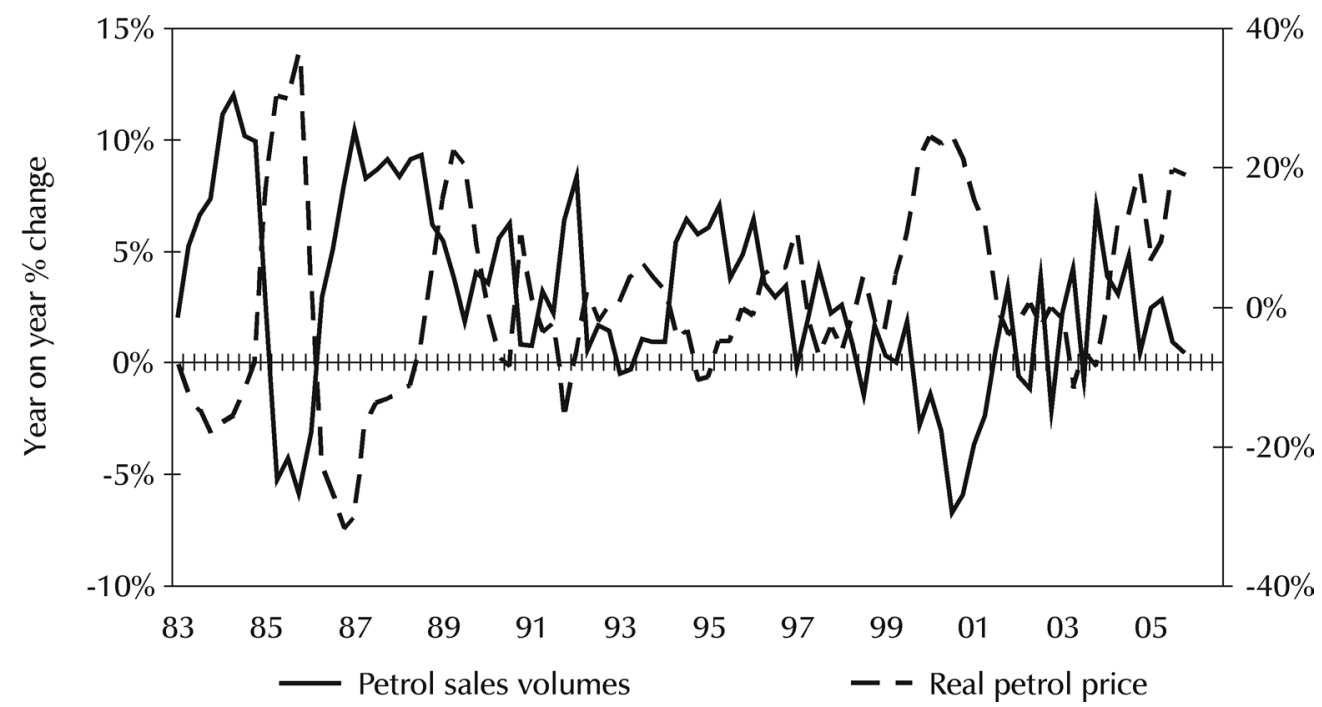

Source: Econex, 2005

The other obvious problem with the petrol demand equation of the merging parties is the omission of an income variable. It was explained above that the income effect is stronger than the price effect in determining petrol demand. If they did not find a strong positive correlation between GDP and petrol demand, another income variable could have been considered such as real disposable income or even a proxy for income such as sales of new vehicles or the stock of new and used vehicles on the road, etc. But there is no justification for omitting the income variable, as this is the most important determinant of petrol demand. Omitting the income variable also ignores completely the positive growth outlook shared by most economists at the time of the proposed merger.

An examination of the growth in the sale of passenger cars over the five years before the merger hearing would already have indicated that the demand for petrol must be increasing over the next few years, as illustrated below (Figure 6). 


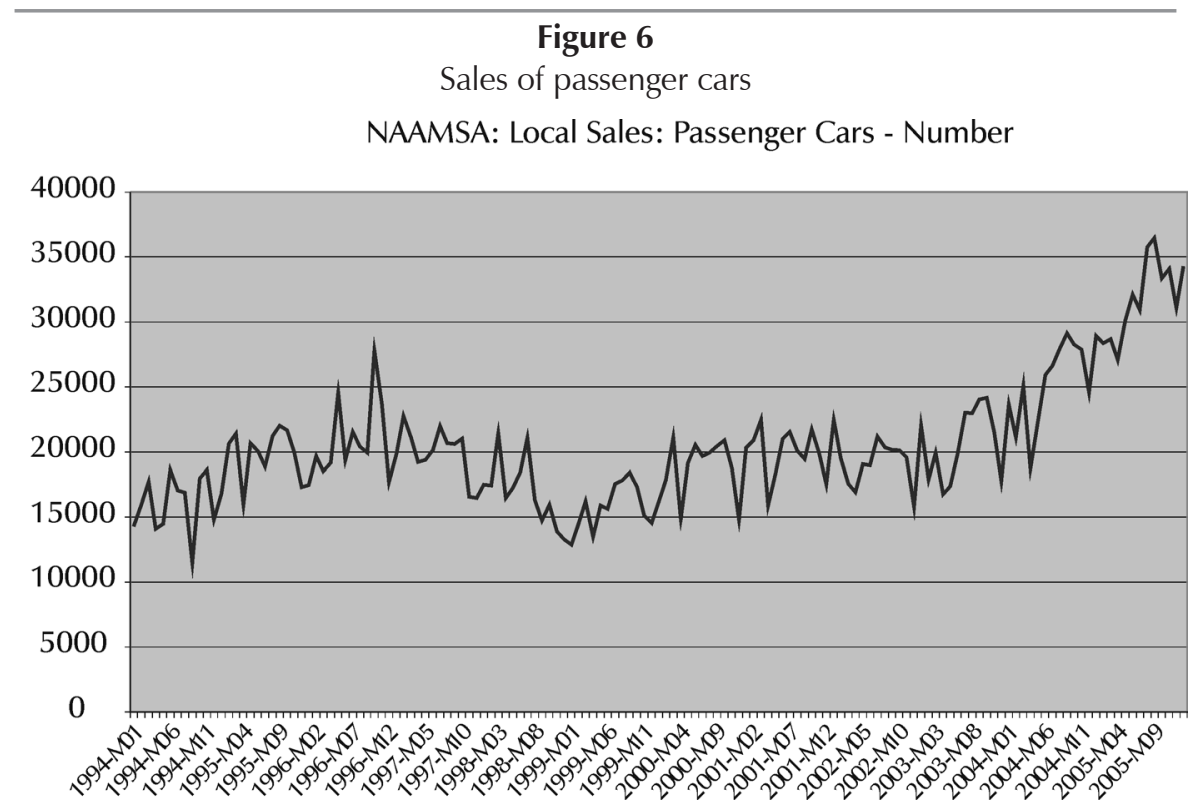

Clearly, the predictions of such a misspecified model, which has no foundation in economic theory, must be disregarded. The Tribunal was correct not to accept the very low petrol demand growth rates (1.4 per cent) that resulted from this model. This caused them to accept that there was a credible threat of foreclosure in the face of higher fuel demand growth rates.

\section{5}

\section{Conclusions}

This paper has argued that although the results of economic models are highly sensitive to the assumptions of the models, this does not mean that such models should not be used. In the case of the Uhambo merger, the most important issue considered by the Tribunal was the possibility or profitability of foreclosure. This in turn was determined mainly by two issues, the growth in fuel demand and the state of logistics.

While the second is primarily a factual issue, the first - white fuels demand growth - is something which can be estimated by economists. Based on economic theory and standard economic analysis, the Tribunal found that the fuel demand growth rates assumed by Uhambo in their business model are "low outliers". This article has shown that assuming a 1 per cent growth rate for petrol demand when the economy was growing at much higher rates and sales of passenger cars were reaching record levels, was indeed conservative, if not totally unrealistic. Changing this assumption in the foreclosure models immediately raised the profitability of foreclosure, and this ultimately led to the Tribunal's conclusion that foreclosure was indeed a "credible threat" and that the proposed merger should therefore be prohibited.

\section{6}

\section{References}

1 BLUM, U.; FOOS, G. \& GUADRY, M. (1988) "Aggregate time series gasoline demand models: Review of the literature and new evidence for West Germany", Transportation Research A, 22A: 75-88.

2 BUREAU FOR ECONOMIC RESEARCH (2003) "The feasibility of a fuel tax levy in the Western Cape", Document for public comment, based on a research report for the Western Cape Provincial Treasury.

3 BUREAU FOR ECONOMIC RESEARCH (2005) "Petrol and diesel sales forecasts for South Africa: 2005 to 2009", Report prepared for BP SA. August 2005.

4 BUSINESS ENTERPRISES, UP (2005)

"Statistical evaluation of SASOL prediction models: Petrol and diesel", Non-confidential version. 
5 COMPETITION TRIBUNAL (2006) "Decision in the large merger between Sasol Ltd, Engen Ltd, Petronas International Corporation And Sasol Oil (Pty) Ltd and Engen Ltd", Case No: 101/LM/ Dec04.

6 DAHL, C. \& ROMAN, C. (2004) "Energy demand elasticities - Fact or fiction: A survey update", Paper presented at the Energy, Environment and Economics in a new Era conference, Washington DC, July 8-10, 2004.

7 DROLLAS, L. (1984) "The demand for gasoline: Further evidence”, Energy Economics, 6: 71-82.

8 ECONEX (2005) "Analysis of the competition aspects of the proposed Uhambo merger $-\mathrm{a}$ Masana perspective", Non-confidential version.

9 ECONOMETRIX (2005) "Estimating long term fuel demand scenarios”, Non-confidential version.
10 GRAHAM, D.J. \& GLAISTER, S. (2002)

"The demand for automobile fuel: A survey of elasticities", Journal of Transport Economics, 36: $1-26$.

11 GOODWIN, P. (1992) "A review of new demand elasticities with special reference to short and long rune effects of price changes", Journal of Transport Economics and Policy, 26: 155-163.

12 RAMANATHAN, R. (1999) "Short and long run elasticities of gasoline demand in India: an empirical analysis using cointegration techniques", Energy Economics, 21: 321-330.

13 STERNER, T. (1990) The Pricing of and Demand for Gasoline, Swedish Transport Research Board, Stockholm. 